\title{
Analysis of Factors that Influence Non-Performing Loans with Econometric Model: Albanian Case
}

\author{
Doc. Fiqiri Baholli \\ Professor in the Faculty of Economy and Agribusiness (AU Tirana) \\ Email: fbaholl@yahoo.com \\ Prof. As. Dr. Ines Dika \\ Professor in the Faculty of Economy and Agribusiness (AU Tirana) \\ Email: ines.dika@virgilio.it \\ MSc. Gjergj Xhabija \\ Research Associate in the Faculty of Economy and Agribusiness (AU Tirana) \\ Email: gjergjixhabija@gmail.com
}

Doi:10.5901/mjss.2015.v6n1p391

\begin{abstract}
International financial crisis of the last decade had a negative influence in almost all banking system of the world. The difficulties on managing problems brought into consideration that the balance of risk exposure versus return is very difficult to be controlled. Managers of the businesses are working hard to meet liquidity needs and to continue their business which is greatly supported by financial intermediaries. On the other side, banks and their regulators are following risk problems with increased management measures, as stability of financial system was undermined seriously from financial crisis and structural problems in all countries. There are several risks that all kind of businesses are exposed, but in this paper we are focused to credit risk in the banking system, which is counted as $60-70 \%$ of total risk exposure. Recently the Albanian economy is having low growth with the banking system suffering from the increase of non- performing loans (NPL). This reflects liquidity and performance problems for businesses with increased risk on financial stability. This paper deals with proof of macroeconomic factors that influence NPL rate for Albania. Verification of these factors can support the proper policies that reduce the NPL level. The analysis includes the comparison of Albanian and Italian data on the trends and factors that affect NPL rate. Albanian Central Bank and government are trying to apply prudent regulations based on analysis of factors driving bad performance. The analysis and findings of this paper is based on existing literature that is applied with a regression model.
\end{abstract}

Keywords: Non-performing loans, Ordinary Least Squares, Gross Domestic Product, interest rate, real effective exchange rate.

\section{Problem Presentation}

Financial intermediation in Albania is dominated from the banking system activity, considering that there is no stock exchange where businesses trade their shares and bonds issued from companies. Other non-bank financial institutions have only 12 per cent of total assets of financial sector. Credit to economy is the main source for financial support of businesses and on the other side the banks have limited investment tools for their deposits. Albania is an importing country and international crisis gives a great impact in trade deficit and domestic performance, but this cannot explain bad performance of lending activity with arrears increasing, expenditures to cover loan loses growing and bad debt going at almost $25 \%$ of loan exposure for the banking system. 
Graph 1: Non-performing loans in Albania (2007 2014)

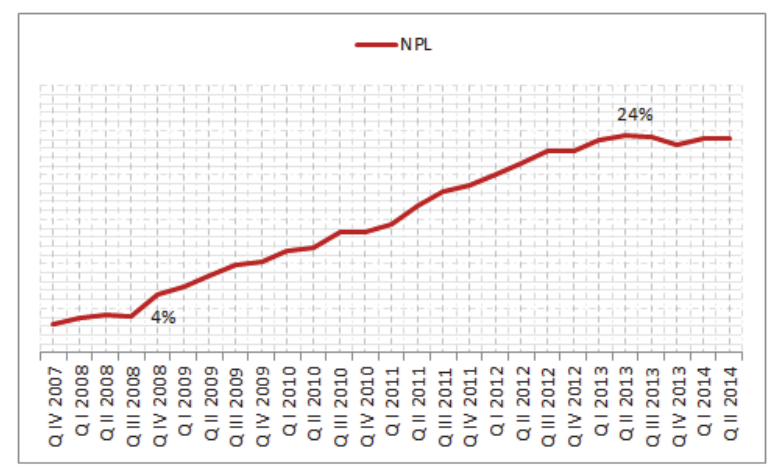

Source: Xhabija Gj. Calculations from Annual Report of Bank of Albania, 2013.

The graph indicates that from $4 \%$ of NPL in 2008 , we have $24 \%$ on the second quarter of 2013 , with an annual average of $4 \%$. The economic situation of Albania has shown difficulties that have reflected influences of domestic and foreign factors. The construction industry is not any more the leading sector that contributes to GDP, followed from the low level of borrowing and liquidity problems on debt service. The domino effect in long term is a great threat, while Albania is listed in the fourth place for NPL to total borrowing of 20 countries.

Graph 2: NPL level for some countries at the end of 2013

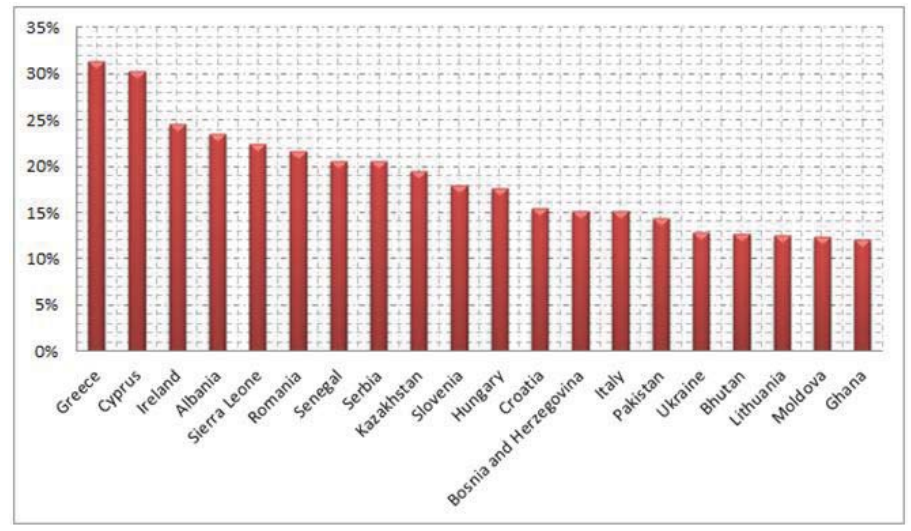

Source: Xhabija Gj. Calculations from Annual Report of Bank of Albania, 2013

The level is pretty high for last two years with banks that have tightened approval procedures, as well as low level of demand for loans from businesses.

This paper tries to analyze the factors that turned loans from performing to non-per forming in Albania, together with mechanisms that could be used to manage this situation. NPL level of Albania will be compared with another European Union country in order to have better analysis.

This paper deals with proof of macroeconomic factors that influence NPL rate for Albania. Verification of these factors can support the proper policies that reduce the NPL level. The analysis includes the comparison of Albanian and Italian data on the trends and factors that affect NPL rate.

\section{Methodology}

The analysis of non-performing loan through econometric modeling is not a new invention. Many researchers have used different econometric methods of explaining the variation on NPL. For example Harvir Kalirai and Martin Scheicher used the simple linear regression model to explain the variation of the NPL in Austria for the period 1990 to 2001. The 
independant variables used in this model were the interest rate for the loans, the inflation and the GDP. They preformed stress tests into this model in order to test the durability of the NPL in an extreme macroeconomic environment. Olena Havrylchyk explained the variation of NPL in South Africa using a linear regression model with factors such as GDP, inflation and interest rate as independant variables. According to this author who also preformed a stress test after building the model, the economy of South Africa is capable to absorb macroeconomic shocks in a way that this shocks could not affect the NPL. Gertjan Vlieghe in his study analysed the credit risk for England usind a autorregresive model. This author comes to the conclusion that the prices of the intanglable assets play a majour role in the default of businesses, because these assets act as colateral for loans.

In this article we will use a simple linear regression model to explain the variation of the non preforming loans in Italy and Albania. In our literature review we came accros many articles that used this model. We think that this model better captures the relationship between the macroeconomic factors (as independent variables) and the non preforming loan (as dependent variable).Moreover we were very limited in the avalibility of data about Albania, thus using the simple linear model was convinient. We will use this model for both countires Italy and Albania, and than we will compare the results between them. I think that this comparison is important because Albania's largest trading partner is Italy, and also both these countries currentlyare experiencing high levels of non preforming loans. Next we will develop credit risk models for both countries, and then we will explain our findings in the last part of this article.

\subsection{Credit risk model}

A model that shows the difference of bad debt level of Albania with Italy is prepared to help analysis of the main macroeconomic factors that have effect on NPL in both countries. Independent variables used in literature are considered to explain their importance on the model. Modeling the behavior of NPL in the macro-economic indicators are used to compare Albanian and Italian economies. Problematic situations are assumed to test the level of NPL increase in two countries.

\subsection{Hypothesis of this study}

There are two main hypothesis aiming to find factors that drive bad debt of Albania and Italy.

\subsubsection{First hypothesis}

Are macroeconomic factors as Gross Domestic Product (GDP), inflation and real exchange rate (RER) constraining bad debt in Albania.

\subsubsection{Second hypothesis}

Are macroeconomic factors as Gross Domestic Product (GDP), inflation and interest rate on loans constraining bad debt in Italy.

\subsubsection{Objective}

Analysis of bad debt level from macro-economic shocks through comparison of Albania and Italy.

\subsection{Data series}

Statistics of the Bank of Albania (central bank) are used for capital ratios and evaluation of banking activity. Quarterly information starting from 2008 until 2014 (first quarter) are used as series of bad debt (dependent variable on the model).

Macroeconomic data, used as independent variables, for Albania are received from Institute of Statistics (INSTAT) and Bank of Albania publications.

For NPL model of Italy are used the data published from Institute of Statistics and Bancad'Italia for the period from third quarter 2008 till second quarter 2014.

Real Exchange Rate (RER) euro/Albanian Lek (ALL) is one of the macro-economic variables that is considered as factor that influences bad debt level (Beck, Roland, Jakubik, Petr, Pilou, Anamaria 2013). The Bank of Albania publishes only nominal exchange rate euro/ALL. RER is calculated using inflation rate of Albania and Italy for each period. Italy is 
one important country on our economic relations. Trade balance shows that Albanian imports from Italy are almost $27 \%$ of total imports during 2005-2008, and Albanian exports to Italy are $67 \%$ of total exports for the same period. The variable is calculated:

$$
\begin{aligned}
& K R=r \times \frac{1+p_{I t}}{1+p_{A l}} \\
& \text { Where: } \\
& K R \rightarrow \text { Re al Exchange Rate } \\
& r \rightarrow \text { No min al Exchange Rate } \\
& p_{I t} \rightarrow \text { Inflation in Italy } \\
& p_{A l} \rightarrow \text { Inflation in Albania }
\end{aligned}
$$

Many authors have used Gross Domestic Product (GDP) as a factor in their studies on credit risk. Pesola 2001, Virolainen 2004, Havrilchyck 2010 showed that since GDP presents economic growth, this factor is very important for the NPL level. Lending to economy is accounted as ratio of credit to economy stock, with the level of GDP on respective periods.

Another macro-economic factor that explains NPL rate is considered inflation. Statistics of Albania and Italy publish quarterly data. Interest rate of loans is analyzed on the impact to NPL.

Model considers interest rate, RER, GDP, inflation and credit to economy as factors that influence the payment capability of borrowers.

Real Exchange Rate is analyzed only for Albania, because it is non-EU member.

\section{Model for Albania}

NPL level is independent variable, while four dependent variables are: GDP, interest rates for loans (NT), inflation (INF). Credit to economy (KRE) and Real exchamge rate euro/ALL (KR).

Several tests on importance of macro-economic factors show the interest rates and inflation as statistically nonimportant for Albania. The model for Albania derives on:

$N P L=c+\beta_{1} K R_{t-2}+\beta_{2} G D P_{t-2}+\beta_{3} K R E_{t-1}+\varepsilon$

Interest rates are used as an important instrument of transmission mechanism channel, but in Albanian case, where lending to economy is allowed in domestic and foreign currency (mainly euro) - the level of interest rate is lower for euro. This explains statistical non-importance of interest rate in the model.

In Italy this functions very well through interest rate mechanism. Two graphs analyze the fluctuation of interest rates in Albania and Italy.

Graph 3. The effect of Interest Rates on credit to economy for Albania.

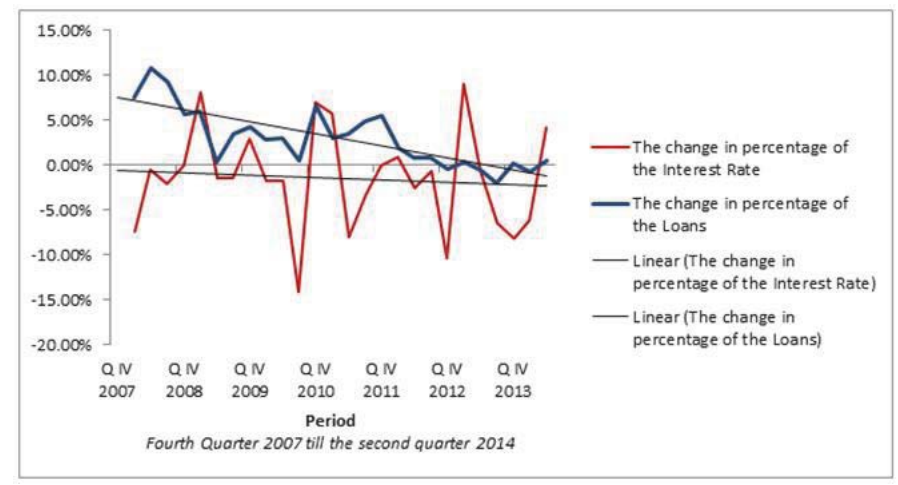

Source: Xhabija Gj. Calculations from Annual Report of Bank of Albania, 2013

Graph 3 for Albania shows that reduction of interest rates from central bank is not affecting lending - that is of the same decreasing tendency. 
Graph 4. The effect of Interest Rates on credit to economy for Italy

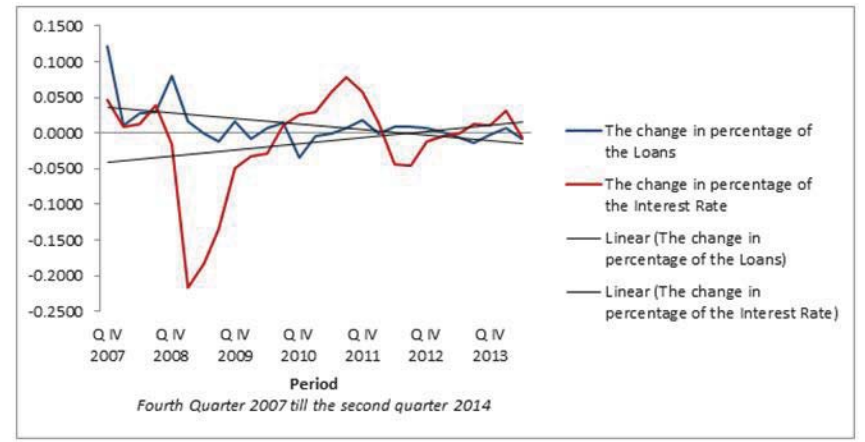

Source: Xhabija Gj. Calculations from Italian Statistics, 2014

Graph 2 for Italy shows clearly that interest rates increase reduces lending and vice versa.

The table 1 shows explanatory statistics on macro-economic variables that are used in the model.

Table 1.

\begin{tabular}{lccccc}
\hline Variable & Notation & Average & Std. Deviation & Minimum & Maximum \\
\hline Real Interest Rate & KR & 135.10 & 7.40 & 121.15 & 146.85 \\
Gross Domestic Product & GDP & 0.018 & 0.111 & -0.130 & 0.205 \\
Credit-To GDP Ratio & KRE & 1.22 & 0.16 & 0.91 & 1.52 \\
\hline
\end{tabular}

Source: Xhabija, Gj calculations based on Italian and Albanian statistics.

\subsection{Model for Italy}

This part of the paper presents the model which explains the fluctuations of bad debt for Italy. Independent macroeconomic factors include: Gross Domestic Product (GDP_IT), interest rates for loans (NINT_IT), Inflation (INF_IT) and credit in Italy (KRE_IT). Dependent variable in this model is rate of non-performing loans in Italy (NPL_IT).

Several tests with the model show inflation rate statistically non-important. The model analyzed is:

$N P L_{-} I T=c+\beta_{1} G D P_{-} I T_{t-2}+\beta_{2} K R E_{-} I T_{t-1}+\beta_{3} N I N T_{-} I T_{t-3}+\beta_{4} N P L_{-} I T_{t-1}+\varepsilon$

A forth variable is added to the model for eliminating serial correlation. Explanations are given for Italy in table 2 .

\begin{tabular}{lccccc}
\hline Variable & Notation & Average & Std. Deviation & Minimum & Maximum \\
\hline Interest Rates & NINT_IT & 4.881 & 1.219 & 3.071 & 7.995 \\
Gross Domestic Product & GDP_IT & 0.008 & 0.031 & -0.030 & 0.014 \\
Credit-To GDP ratio & KRE_IT & 10.038 & 3.187 & 5.353 & 14.064 \\
\hline
\end{tabular}

Comparison between Albania and Italy show that lending level (credit to economy/GDP) is higher in Italy. On average for the period $4^{\text {th }}$ Quarter 2007 to $2^{\text {nd }}$ Quarter 2014 is almost 11 times higher in Italy than in Albania.

Italian GDP shows a decreasing tendency, reflecting the impact of international financial crisis.

\subsection{E-view results}

Models on fluctuations of non-performing loans in Albania and Italy are prepared using statistical program e-views. Table 5 and graphs are generated from the information using this program. 
Table 3: Fluctuations of NPL in Albania

\begin{tabular}{|c|c|c|c|c|}
\hline \multicolumn{5}{|c|}{$\begin{array}{l}\text { Dependent Variable: LOG(NPL) } \\
\text { Method: Least Squares } \\
\text { Date: 10/07/14 Time: 01:31 } \\
\text { Sample(adjusted): 2008:3 2014:2 } \\
\text { Included observations: } 24 \text { after adjusting endpoints }\end{array}$} \\
\hline Variable & Coefficient & Std. Error & t-Statistic & Prob. \\
\hline LOG(GDP(-2)) & -1.415530 & 0.619979 & -2.283190 & 0.0329 \\
\hline LOG(KR(-2)) & 5.658713 & 1.579850 & 3.581804 & 0.0018 \\
\hline LOG(KRE(-1)) & 3.819152 & 0.386645 & 9.877661 & 0.0000 \\
\hline R-squared & 0.877209 & Mean depend & & 10.83673 \\
\hline Adjusted R-squared & 0.865515 & S.D. depende & & 0.664007 \\
\hline S.E. of regression & 0.243506 & Akaike info cri & & 0.129116 \\
\hline Sum squared resid & 1.245196 & Schwarz crite & & 0.276373 \\
\hline Log likelihood & 1.450604 & F-statistic & & 75.01148 \\
\hline Durbin-Watson stat & 2.319685 & Prob(F-statis & & 0.000000 \\
\hline
\end{tabular}

Table 4: Fluctuations of NPL in Italy

\begin{tabular}{|c|c|c|c|c|}
\hline $\begin{array}{l}\text { Dependent Variable: } \\
\text { Method: Least Squar } \\
\text { Date: 10/07/14 Time } \\
\text { Sample(adjusted): } 19 \\
\text { Included observation }\end{array}$ & 2 & & & \\
\hline Variable & Coefficient & Std. Error & t-Statistic & Prob. \\
\hline $\mathrm{C}$ & 15.37264 & 3.648427 & 4.213499 & 0.0001 \\
\hline LOG(GDP_IT(-2)) & -1.202354 & 0.283485 & -4.241331 & 0.0001 \\
\hline LOG(KRE_IT(-1)) & 0.145541 & 0.029014 & 5.016294 & 0.0000 \\
\hline LOG(NINT_IT(-3)) & -0.081386 & 0.035835 & -2.271114 & 0.0270 \\
\hline LOG(NPL_IT(-1)) & 0.901516 & 0.030171 & 29.88060 & 0.0000 \\
\hline R-squared & 0.989378 & \multicolumn{2}{|c|}{ Mean dependent var } & -2.684916 \\
\hline Adjusted R-squared & 0.988619 & \multicolumn{2}{|c|}{ S.D. dependent var } & 0.385695 \\
\hline S.E. of regression & 0.041146 & \multicolumn{2}{|c|}{ Akaike info criterion } & -3.464946 \\
\hline Sum squared resid & 0.094810 & \multicolumn{2}{|c|}{ Schwarz criterion } & -3.291924 \\
\hline Log likelihood & 110.6809 & \multicolumn{2}{|c|}{ F-statistic } & 1303.996 \\
\hline Durbin-Watson stat & 2.162338 & \multicolumn{2}{|c|}{ Prob(F-statistic) } & 0.000000 \\
\hline
\end{tabular}

\section{Findings and Analysis}

The linear regression analysis using least squares method is used for Albania and Italy. Results are presented in the table 3. Both models that explain Non Performing Loans behavior for Albania and Italy resulted of a great statistical importance with a confidence less than 1\%. Explanations of NPL fluctuations in Italy is approximately $99 \%$ and $88 \%$ for Albania. Regression is realized for a period from $4^{\text {th }}$ Quarter 2007 till $2^{\text {nd }}$ Quarter 2014, counting 24 observations in Albania. In Italy the regression, analyzed a period from $3^{\text {rd }}$ quarter 2008 to $2^{\text {nd }}$ Quarter 2014, with 61 observations. Lag differences are formulated based on the usage of other authors. 
Table 5. Macro-economic model of credit risk for Albania and Italy

\begin{tabular}{|c|c|c|c|c|c|c|c|}
\hline \multirow{2}{*}{ Variable } & \multirow{2}{*}{ Notation } & \multicolumn{3}{|c|}{ Albania } & \multicolumn{3}{|c|}{ Italy } \\
\hline & & $\begin{array}{c}\text { Lag } \\
-\end{array}$ & $\begin{array}{c}\text { Coefficient } \\
\text { NA }\end{array}$ & Std. Error & Lag & $\begin{array}{c}\text { Coefficient } \\
15,23^{\star \star \star}\end{array}$ & $\begin{array}{c}\text { Std. Error } \\
3,65\end{array}$ \\
\hline Interest Rate & NINT & - & NA & - & -3 & $-0,08^{\star \star \star}$ & 0,04 \\
\hline Real Exchange Rate & $\mathrm{KR}$ & -2 & $5,66^{\star \star \star}$ & 1,58 & - & NA & - \\
\hline Gross Domestic Product & GDP & -2 & $-1,42^{\star \star \star}$ & 0,62 & -2 & $-1,32^{\star \star \star}$ & 0,30 \\
\hline Credit to GDP ratio & KRE & -1 & $3,82^{\star \star \star}$ & 0,39 & -1 & $0,14^{\star \star \star}$ & 0,03 \\
\hline Non-Performing Loans & NPL & - & NA & - & -1 & $0,90 \star \star \star$ & 0,03 \\
\hline
\end{tabular}

Levels of statistical significance: ${ }^{\star * *}$--- $1 \%$ significant level and ${ }^{* \star}$--- $5 \%$ significant level.

The models are statistically significant at $1 \%$ level. The model for the case of Albania explains at $88 \%$ level the variance of NPL and the model for the case of Italy explains at 99\% level the variance of NPL.

Real Interest Rate (KR) has a positive effect on NPL increase. This is typical for importing countries, as national currency depreciates making more expensive imports. Albanian businesses that import most of raw materials will have problems on debt service going this way to arrears and bad debt. KR coefficient show, that appreciation of ALL with $1 \%$, increases NPL level by $5.66 \%$ after a quarter.

Interest rate (NINT) has a negative impact on NPL fluctuations. Other authors that used this variable on their analysis conclude that increase on NINT influences NPL increase. This due to more expensive loans, that in return have less payment capabilities. In Italian case this is a contrary effect where 1\% increase on NINT, decreases NPL level by $0.08 \%$.

Regression explains that, GDP level as independent variable, influences negatively on bad debt level. NPL level is reduced when GDP increases, because economic growth shows the improvement of business performance. This performance improves their payment capabilities. $1 \%$ increase of GDP, decreases by $1,42 \%$ the level of bad debt in Albania. In Italy the effect shows a 1,32\% decrease in NPL for $1 \%$ increase in GDP.

Credit to economy (KRE).Credit to economy is the ratio of total credit to GDP. The model indicates that. When lending increases the probability for NPL increase is higher. When an economy has a high level of credit to economy, an economic crises will make businesses suffering liquidity problems.

As shown in the table, in Albania $1 \%$ credit increase can raise the NPL level by $3.82 \%$. For Italy, $1 \%$ increase on lending to economy will influence only $0.14 \%$ the NPL level.

Albania shows more risk exposure to macro-economic shocks.

According to BOA statistics, Albania is listed at the $4^{\text {th }}$ place for the non-performing loans level. This is a problematic situation that shows a non-performing economy and, on the other hand financial institutions that are having difficulties in intermediation, while posting losses for their businesses. The increase of NPL level last four years has been counted for $4 \%$ a year. In this way banks are tightening their lending, but the economy is suffering liquidity problems.

The Bank of Albania (central bank) has reduced base interest rate at historical minimum level (2.5\%), but this policy seems to have no effect at all. Several factors can be considered for low lending level:

- International economic crises,

- Less remittances from emigrants,

- Reduction of activity in construction industry (considered to be leading industry with important contribution in GDP during 2002 - 2009).

Considering the significance of NPL level in Albania, it is important to find out which are the macro-economic factors that influence this level. These factors are analyzed with a linear macro-economic model, where independent variables are: GDP, lending to economy, real exchange rate.

Regression analysis proved that if lending increases, NPL increases too. Therefore decreasing trend in NPL could result because of lending reduction. This is not good in both sides: business needs lending GDP level will be lower without business activity.

The model suggests that GDP increase influences on reduction of NPL level.

Albanian Lek depreciation will make more expensive foreign currency loans and debt service will be more difficult as well (NPL will go up).

Albanian government must be very prudent treating bad debts on the financial system. All possible instruments that facilitate the reduction of non-performing loans level should be used. Model explained in this paper concludes that bad debt can be reduced if government works with fiscal and monetary policies to have GDP growth, stabilize lending process 
with higher levels of intermediation and stable domestic currency. Model shows that lending increases NPL level, but less credit means less liquidity and economic growth.

\section{References}

Bank of Albania, (2013, Tetor 23). Norma mesatare e kredisë mujore në lekë për sistemin bankar. Tirana, Albania.

Bank of Albania. (2009). Buletini I Bilancit të Pagesave. Tirana, Albania.

Beck, Roland; Jakubik, Petr; Piloiu, Anamaria;. (2013). Non-Performing loans what matters in addition to the economic cycle? 1515 (QBAR-13-012-EN-N (online).

INSTAT "Instituti I Statistikave të Shqipërisë". (2013, Tetor 23). Ndryshimi i PBB tremujore. Tirane, Albania.

INSTAT. (2013, Tetor 23). VSHB tremujore sipas aktivitetit ekonomik me cmime konstante, vlerat të pa zhveshura nga efektet sezonale. Tirane, Albania.

INSTAT (2005-2013). Norma e Inflacionit sipas Çmimeve të Konsumatorit. Tiranë, Albania. -

Istituto di Statistica, Italia. (2005-2013). Consumer Prices Index in Italy.

Lusha, A., Aliaj, D., \& - Xhabija, G. (Nentor 2013). Ndikimi I Kredidhenies Ne Rritjen Ekonomike. Tiranë: Research Paper. Universiteti Bujqesor I Tiranes

Xhabija, Gj. (Tetor 2014) Luhatshmeria e normes se kredive te keqija me modelimin ekonometrikdhe stress testin: krahasimi midis Shqiperise dhe Italise. Mikroteze per Master Shkencor.

Myslym, O. (2010). Ekonometri (me zbatime). Tiranë.

Pesola, J. (2001). The role of macroeconomic shocks in banking crises.

Rinaldi, L., \&Sanchis-Arellano, A. (2006). Household debt sustainability, what explains household non-performing loans? An empirical analysis. 570.

Shingjergji, A., \&Shingjergji, I. (2013). An Analysis of the Nonperforming Loans in the Albanian Banking System. 2 (6).

Vlieghe, G. (2001). Indicators of fragility in the UK corporate sector.

\section{Appendix}

\section{The performance of models for Albania and Italy}

The performance of models analyzed for non-performing loans is illustrated with the following graphs. Time frame for Albania is from $3^{\text {rd }}$ Quarter 2008 till 2nd Quarter 2014. For Italy it is from 2nd Quarter 1999 till 2nd Quarter 2014.

Graph 1: NLP model performance for Albania

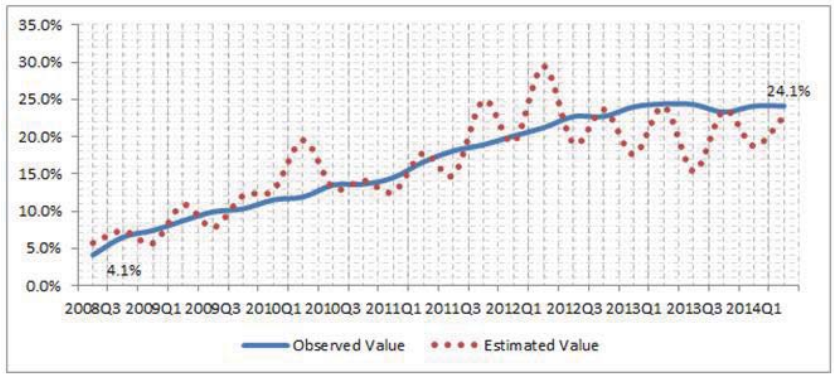

Graph 1 shows the performance of Albanian level of NPL with ratio to outstanding loans in the banking system 4,1\% on 3rd Quarter 2008, to $24,1 \%$ at $2^{\text {nd }}$ Quarter 2014. The model shows the uptrend with accuracy.

Graph 2: NPL performance for Italy

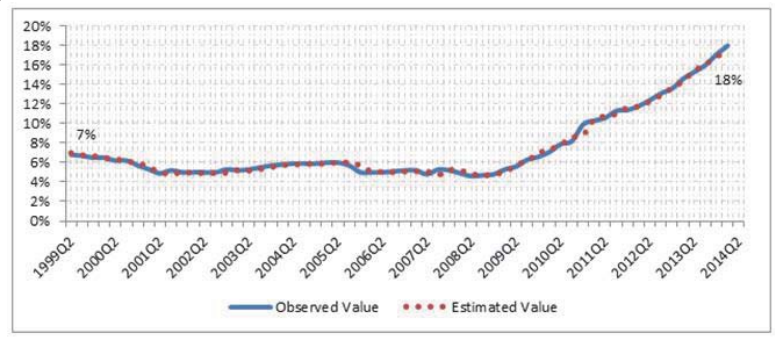

The graph 2 explains the NPL level with more precision. NPL in Italy have been 7\% in 1999 and has gone to 18,4\% in 2014 .

The Albanian case has less data series that limits the calculations for longer period of time. 